\title{
Leishmaniasis: Bone Marrow Aspirate Smear and Rapid Antibody Test
}

\author{
Layşmanyazis: Kemik Iliği Aspirasyon Yayması ve Hızlı Antikor Testi
}

Beuy Joob ${ }^{1}$, Viroj Wiwanitkit ${ }^{2}$

${ }^{1}$ Sanitation 1 Medical Academic Center, Bangkok, Thailand

${ }^{2}$ DY Patil University Faculty of Medicine, Pune, India

To the Editor,

The publication by Dorji et al. [1], "Microscopic Image of Leishman-Donovan Bodies in Bone Marrow Aspirate Smear of Patient Suffering from Unexplained Intermittent Low-Grade Fever and Cough", is very interesting. Indeed, the clinical presentation of leishmaniasis is usually nonspecific and it is hard to discriminate it from other tropical infections [2]. However, the common presentation that might be useful for the inclusion of leishmaniasis in differential diagnosis is splenomegaly [2]. In the present report, an important observation is a negative antibody test for Leishmania pathogens. The gold standard for the diagnosis of leishmaniasis is usually the examination of the blood or marrow and identification of the parasite. However, it is considered harmful. A new rapid test might be a solution and a less invasive technique. Nevertheless, the problem of the diagnostic properties of the available rapid test is frequently reported [3]. There are many possible explanations for false negative results. One important explanation is the prozone phenomenon [4] due to heavy infection. In the present case, there might be parasites and excessive antigens that could induce false negative results due to the immunological testing and the dilution of the blood sample before the test could be a simple method to reduce the problem of the prozone effect. Focusing on the examination of bone marrow a spirates, a similar problem with diagnostic false negatives can be expected [5]. At present, the test with the best diagnostic properties is the polymerase chain reaction-based test [5].
Keywords: Leishmaniasis, Bone marrow, Aspirate, Smear, Antibody

Anahtar Sözcükler: Layşmanyazis, Kemik iliği, Aspirasyon, Yayma, Antikor

Conflict of Interest: The authors of this paper have no conflicts of interest, including specific financial interests, relationships, and/or affiliations relevant to the subject matter or materials included.

\section{References}

1. Dorji K, Tobgay $T$, Jamtsho R, Samal PD, Rai P. Microscopic image of Leishman-Donovan bodies in bone marrow aspirate smear of patient suffering from unexplained intermittent low-grade fever and cough. Turk J Hematol 2017;34:266-267.

2. Wiwanitkit $\mathrm{V}$. Bone marrow leishmaniasis: a review of situation in Thailand. Asian Pac J Trop Med 2011;4:757-759.

3. Khan MG, Alam MS, Bhuiyan AT, Jamil MA, Saha B, Islam M, Haque $R$, Hossain M, Jamil KM. Short communication: evaluation of a new rapid diagnostic test for quality assurance by kala azar elimination programme in Bangladesh. J Parasitol Res 2011;2011:862475.

4. Itoh $Y$, Yamaguchi T. Factors that affect analytical results in an enzyme immunoassay. Nihon Rinsho 1995;53:2143-2148.

5. Piarroux R, Gambarelli F, Dumon H, Fontes M, Dunan S, Mary C, Toga B, Quilici M. Comparison of PCR with direct examination of bone marrow aspiration, myeloculture, and serology for diagnosis of visceral leishmaniasis in immunocompromised patients. J Clin Microbiol 1994;32:746-749. 